\title{
PENGEMBANGAN KERUPUK PENTOL IKAN DI DESA LEGUNG TIMUR KECAMATAN BATANG-BATANG
}

\author{
Fatmawati $^{1}$, Moh. Kurdi ${ }^{2}$ \\ ${ }^{1)}$ Dosen Fakultas Pertanian Universitas Wiraraja \\ ${ }^{2)}$ Dosen Fakultas Ekonomi dan Bisnis Universitas Wiraraja \\ Email: ${ }^{1)}$ fatmawati@wiraraja.ac.id, ${ }^{2)}$ mkurdi@wiraraja.ac.id
}

\begin{abstract}
ABSTRAK
Desa Legung Timur merupakan salah satu sentra pengrajin kerupuk pentol yang berbahan dasar ikan di Kecamatan Batang-batang Kabupaten Sumenep. Kerupuk pentol ikan yang diproduksi oleh masyarakat mayoritas dalam bentuk 'mentah' yang harus melalui proses penjemuran terlebih dahulu untuk kemudian digoreng. Bahan baku pembuatan kerupuk pentol berupa ikan sangat melimpah di desa ini dan sebagian besar masyarakatnya bermata pencaharian sebagai nelayan. Ikan yang digunakan untuk bahan baku pembuatan kerupuk adalah ikan tongkol. Sebagian besar, hasil produksinya dijual di rumah mereka sendiri dengan menunggu konsumen datang untuk membeli ataupun dibeli kerabat sendiri untuk oleh-oleh. Beberapa situasi yang dialami pengrajin kerupuk di Desa Legung Timur tersebut diatas menjadi penyebab bahwa mereka membutuhkan pelatihan dan pendampingan mengenai cara pengadonan dan pencetakan kerupuk, penyeragaman kuantitas, teknologi kemasan dan pelabelan. Perbaikan kualitas produksi akan meningkatkan produktivitas kerja dengan waktu yang lebih efisien dan kapasitas produksi yang bertambah, serta produk yang mempunyai daya jual dan daya saing lebih tinggi di pasaran. Dari hasil pelaksanaan Pengabdian kepada masyarakat Usaha Kerupuk di Desa Legung Timur Kecamatan Batang-batang Kabupaten Sumenep telah dapat dijalankan dengan baik dan tanpa halangan yang berarti. Dengan kerjasama tim pengabdian yang baik dan peran serta aktif dari penyuluh/narasumber dalam kegiatan pengabdian ini maka semuanya telah berjalan sesuai yang diharapkan dan harapannya dapat memberikan manfaat bagi mitra pengabdian kepada masyarakat dalam keberlanjutan usaha kerupuk pada mitra pengrajin kerupuk. Pengabdian yang kami lakukan ini telah sampai pada tahapan dilaksanakannya kegiatan pelatihan tentang proses produksi yang efisien.
\end{abstract}

Kata kunci: Kerupuk, Pentol Ikan, Kemasan, Pemasaran

\section{PENDAHULUAN}

Desa Legung Timur merupakan salah satu sentra pengrajin kerupuk pentol yang berbahan dasar ikan di Kecamatan Batangbatang Kabupaten Sumenep. Kerupuk pentol ikan yang diproduksi oleh masyarakat mayoritas dalam bentuk 'mentah' yang harus melalui proses penjemuran terlebih dahulu untuk kemudian digoreng. Bahan baku pembuatan kerupuk pentol berupa ikan sangat melimpah di desa ini dan sebagian besar masyarakatnya bermata pencaharian sebagai nelayan. Ikan yang digunakan untuk bahan baku pembuatan kerupuk adalah ikan tongkol. Sebagian besar, hasil produksinya dijual di rumah mereka sendiri dengan menunggu konsumen datang untuk membeli ataupun dibeli kerabat sendiri untuk oleh-oleh. Pengrajin mengalami kesulitan pendistribusian karena untuk pendistribusian ke dalam dan luar kota, produk mereka masih kalah bersaing dengan yang ada di kota-kota besar. Jika diamati kemungkinan ada beberapa hal yang mempengaruhi hal tersebut terjadi, yaitu dikarenakan produk kerupuk pentol ikan yang mereka produksi dikemas dalam kemasan yang kurang menarik, tidak ada informasi mengenai produk seperti berat bersih dan komposisi bahan, serta seringkali 
dalam satu kemasan bentuk kerupuk tidak sama besar.

Hollensen (2003) menyebutkan bahwa ada 4 atribut produk yang mempengaruhi pertimbangan konsumen dalam membeli produk, salah satunya adalah atribut kinerja yang meliputi ketahanan, kualitas material, konstruksi, ketergantungan, kinerja fungsi. Contoh: kecepatan, kandungan nutrisi, rasa, efisiensi, keselamatan dan style. Menurut Sunyoto (2013) dalam menentukan keputusan pembelian yang dilakukan oleh konsumen memiliki struktur. Struktur keputusan pembelian salah satunya adalah tentang keputusan bentuk produk yang akan dibeli. Konsumen akanmelakuka pertimbangan dari berbagai cara, diantaranya adalah ukuran, mutu, corak dan sebagainya. Produsen harus senantiasan selalu memperhatikan keinginan konsumen terhadap produk yang bersangkutan agar dapat dapat memaksimalkan daya tarik dari merek produk.

Terdapat 15 keluarga pengrajin kerupuk pentol ikan di Desa Legung Timur yang aktif berproduksi. Namun, proses produksi belum bisa dilakukan setiap hari dikarenakan beberapa hal seperti jumlah pekerja yang terbatas, dimana kurang lebih hanya 2 orang pekerja untuk setiap rumah pengrajin kerupuk, selain itu juga dikarenakan ketersedian bahan baku ikan tongkol yang tidak setiap hari ada.

Dari 15 pengrajin yang aktif, belum ada pengrajin yang memiliki izin PIRT (Pangan Industri Rumah Tangga) dari Dinas Kesehatan (Dinkes). Namun, kendala yang dihadapi oleh pengrajin disini rata-rata sama. Kendala yang dihadapi saat ini adalah dalam proses produksi. Padahal proses produksi ini sangat mempengaruhi produk yang dihasilkan. Alat produksi yang digunakan pengrajin dalam melakukan proses produksi semuanya masih manual. Mulai dari mencampur adonan, mencetak, mengukus, mengiris serta menjemur juga sangat tergantung pada panas matahari, sehingga apabila musim penghujan datang akan sulit sekali mendapat kerupuk yang siap dipasarkan. Dari segi ukuran kerupuk pun cenderung tidak konsisten karena dalam mencetak adonan berbentuk silinder (lontongan) hanya menggunakan tangan sedangkan untuk mengiris adonan silinder (lontongan) yang telah dikukus masih manual. Alat produksi yang masih manual ini berdampak pula pada jam kerja yang tidak efektif serta hasil produksi yang dihasilkan tidak maksimal. Keuntungan dalam menggunakan teknologi modern dainatranya adalah hasil lebih banyak, bentuk dan mutunya sama, dan waktunya lebih cepat.

Hampir semua pengrajin dalam pengemasan kerupuk yang siap dipasarkan kurang menarik dan cenderung sangat sederhana sekali. Yang dikatakan kurang menarik disini adalah pengemasnya berupa kantong plastik ukuran $1 \mathrm{~kg}$, kemudian ditutup dengan staples atau karet gelang, tanpa ada informasi sama sekali mengenai berat bersih ataupun komposisi produk. Seperti yang diperoleh dari sumber Balai Besar Kimia dan Kemasan bahwa informasi netto (berat bersih) pada kemasan merupakan salah satu syarat informasi yang harus dicantumkan pada label kemasan. Dengan kondisi pengemasan produk yang seperti ini mengakibatkan produk kerupuk memiliki pasar yang sangat terbatas. Sementara produk sejenis sudah banyak yang dipasarkan di toko-toko maupun supermarket. Padahal, soal rasa, produk kerupuk pentol ikan yang dihasilkan tidak kalah bersaing dengan produk kerupuk yang sudah ada dipasaran. Hal ini pula yang merupakan faktor penyebab kerupuk pentol ikan tersebut belum bisa 
bersaing di toko pusat oleh-oleh maupun swalayan. Cenadi (2009) menyatakan bahwa kemasan memiliki peranan penting dalam bidang promosi, yaitu silent sales person. Peningkatan kualitas kemasan menarik perhatian konsumen-konsumen baru secara efektif.

Beberapa situasi yang dialami pengrajin kerupuk di Desa Legung Timur tersebut diatas menjadi penyebab bahwa mereka membutuhkan pelatihan dan pendampingan mengenai cara pengadonan dan pencetakan kerupuk, penyeragaman kuantitas, teknologi kemasan dan pelabelan. Melalui teknologi yang akan diintroduksi kepada pengrajin dengan tujuan perbaikan bentuk produk, kuantitas dan pengemasan kerupuk melalui fasilitasi alat berupa mesin pencampur adonan kerupuk, mesin pencetak adonan kerupuk silinder, mesin pemotong adonan silinder yang telah dikukus dan hand sealer (pengemas) dapat mudah diadopsi oleh pengrajin.

\section{METODE}

Solusi yang ditawarkan pada pengrajin kerupuk pentol ikan meliputi beberapa tahapan kegiatan yaitu:

a. Melakukan fasilitasi mesin pencampur adonan kerupuk, pencetak adonan siap kukus serta pencetak lembaran kerupuk siap jemur.

b. Melakukan fasilitasi alat pengemas yaitu mesin hand sealer.

c. Melakukan pendampingan dan perbaikan desain label kemasan untuk meningkatkan daya tarik konsumen terhadap produk kerupuk mentah.

d. Demonstrasi dan pelatihan untuk menggunakan mesin pencampur adonan, mesin pencetak adonan siap kukus, serta mesin pencetak kerupuk siap jemur,dan mengemas kerupuk dengan alat hand sealer.
Dalam pelaksanaan kegiatan pengabdian kepada masyarakat ini tidak akan bisa berhasil dengan maksimal tanpa dukungan dan partisipasi dari mitra. Yang dimaksud mitra disini adalah pengrajin kerupuk pentol ikan di Desa Legung Timur Kecamatan Batang-batang Kabupaten Sumenep. Bentuk partisipasi mitra antara lain:

a. Pengrajin kerupuk pentol ikan berpartisipasi dalam menyediakan bahan bakuikan tongkol serta tenaga kerja dalam pelaksanaan kegiatan PengabdianKepada Masyarakat terutama dalam rangka demonstrasi dan pelatihan.

b. Pengrajin memiliki motivasi untuk meningkatkan kinerja usahanya melaluiperbaikan kualitas produk dan kuantitas produksi.

c. Tim pelaksana akan melakukan monitoring dan evaluasi secara periodiktentang pelaksanaan dan kemajuan hasil kegiatan pengabdian masyarakatsehingga keberhasilan kegiatan dapat menjadi motivasi untuk pengrajinkerupuk pentol ikan yang lain dalam berproduksi.

d. Pengrajin mempunyai keinginan dan komitmen untuk menggunakan mesinsealer dalam mengemas produk kerupuk pentol ikan, tidak lagi menggunakanstaples maupun karet gelang serta menyertakan label kemasan dalam produkkerupuk pentol ikan yang dihasilkan.

\section{HASIL DAN PEMBAHASAN}

Rencana program pelaksanaan pengabdian kepada masyarakat ini dimulai dari kegiatan survei identifikasi masalah mitra, perumusan permasalahan, survei lapangan potensi yang ada sehingga bisa digunakan untuk memecahnkan masalah, menyiapkan tempat demonstrasi/praktek dan pelatihan, pendampingan, praktek pelaksanaan program, evaluasi kegiatan dan 
pelaporan. Pada tahap pelaksanaan kegiatan dilaksanakan dari bulan Mei sampai pada bulan Oktober 2019 yang telah dilaksanakan. Awal kegiatan yang dilakukan adalah memberikan pelatihan proses produksi kerupuk.

Tahap awal untuk pelaksanaan program pengabdian kepada masyarakat yaitu melakukan koordinasi dengan pengrajin tentang persiapan sarana dan prasarana, bahanbaku serta bahan pendukung yang akan digunakan untuk kegiatan pelatihan. Kegiatan ini dilaksanakan pada tanggal 20 Mei sampai dengan bulan 18 Oktober 2019 yang juga disi dengan memberikan sosialisasi penataan tempat produksi.

Program selanjutnya adalah mempersiapkan instruktur yang menguasai pada bidang yang berkaitan dengan tema pelaksanaan pengabdian.Proses persiapan instruktur dilakukan pada tahap awal kegiatan, hal ini dilakukan untuk mematangkan program-program yang akan dilaksanakan kepada mitra.Pada tahap ini meliputi: pembuatan materi, mempersiapkan materi pelatihan dan pendampingan.

Pada tahap berikutnya adalah melakukan koordinasi untuk menentukan waktu kegiatan yang dalam hal ini melibatkan mitra. Hal ini dilakukan untuk mendapatkan waktu yang tepat dan pas, sehingga kegiatan pelatihan tidak mengganggu kegiatan produksi. Selain itu, juga dilakukan koordinasi pada Kepala desa untuk mendapatkan ijin kegiatan dan legitimasi dari pemerintahan desasehingga kegiatan pelatihan dan pendampingan dapat berlangsung dengan lancar.

Pada pelaksanaan pendampingan pengelolaan sistem produksi yang tepat mulai dari pemilihan bahan baku, proses produksi, dan penataan tempat produksi. Kegiatan ini dilaksanakan dari tanggal 5 Agustus 2019 sampai dengan tanggal 14 September 2019, dengan peserta pengrajin kerupuk pentol, pada pelaksanaan ini materi diberikan oleh Ir. Fatmawati, MP dan Moh. Kurdi, SP., MM. Kegiatan berjalan dengan baik dan lancar karena mendapatkan respon yang baik dari peserta terhadap materi yang diberikan. Hal ini ditunjukkan dengan antusias peserta yang ikut dalam pelatihan ini, sehingga diharapkan dengan materi yang didapatkan ini mampu meningkatkan kemampuan para pengarajin kerupuk dalam mengelola sistem produksi kerupuk mulai dari pemilihan kerupuk, penjemuran, proses penggorengan sampai penantaan tempat produksi

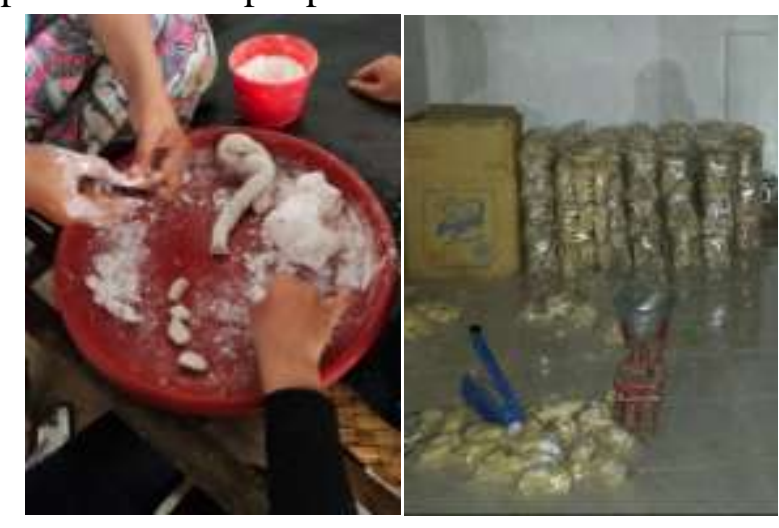

Gambar 1. Proses Pembuatan dan Hasil Produk Kerupuk Pentol

Pelatihan ini dimulai dengan memberikan materi tentang pemilihan kerupuk yang tepat yaitu kerupuk yang baik dengan tanpa menggunakan pewarna sehingga aman bagi kesehatan.Kemudian juga proses penjemuran yang higienis terjaga dari kotoran dan debu.Hal ini sangat perlu diajarkan. Proses pemberian bumbu juga disosialisasikan penggunaan rempah-rempah alami tanpa penambahan bahan pengawet ataupun penyedap rasa. Ditekankan penggunaan bumbu rempah yang segar. Dengan kesegaran rempah yang digunakan maka berpengaruh terhadap rasa.Pengaturan komposisi yang tepat dan jumlah yang sesuai takaran. 


\section{SIMPULAN}

Pengabdian kepada masyarakat Usaha Kerupuk di Desa Legung Timur Kecamatan Batang-batang Kabupaten Sumenep dapat dilaksanakandengan baik tanpa adanya halangan. Hal ini berkat adanya kerjasama yang baik baik dari tim pengabdian maupun peran serta aktif dalam kegiatan pengabdian ini. Sehingga dengan adanya pelaksanaan pengabdian kepada masyarakat ini diharapkan dapat memberikan manfaat bagi mitra pengabdian kepada masyarakat dalam keberlanjutan usaha kerupuk pada mitra pengrajin kerupuk. Pengabdian yang kami lakukan ini telah sampai pada tahapan dilaksanakannya kegiatan pelatihan tentang proses produksi yang efisien.

\section{DAFTAR PUSTAKA}

Balai Besar Kimia dan Kemasan. 2014. Peraturan Kemasan dan Pedoman Umum Pelabelan.

BBKK. Kementrian Perindustrian Republik Indonesia. Jakarta.

Cenadi. 1999. Elemen-elemen dalam desain Kemasan Visual. Jurnal Nirmana 1(1).

Hollensen, S. 2003. 'Marketing ManagementA Relationship Approach, Upper Saddle River'. New Jersey: Prentice Hall

Sunyoto, D. 2013. Teori, Kuesioner \& Analisis Data. Yogyakarta: Graha Ilmu. 